\title{
Migration Violence in the \\ Great Lakes Region of Africa: \\ Negotiating the Return of Refugees
}

\section{Fred Bidandi}

\section{Abstract}

The zeal for humanity to have an identity and belonging to a civilized community is increasing globally. However, this has brought challenges to human cohabitation as witnessed from the xenophobic attacks on migrants in cities across South Africa and lately in Zambia which will always remind refugees that they never belong to the country of asylum. The Great Lakes region is a place found to be the heart of a profound refugee crisis as a result of regional geopolitical ramification related to the identity on one hand and resource allocation on the other. The seeds of violence in countries and the ones under investigation were sown in the early 1960s, to date, producing an enormous movement of refugees across the region and beyond. Refugees tend to be ignored while in exile and they are constantly faced with security problems. It should be noted that no clear mechanisms by regional governments to collectively address refugee matters, especially those related to political violence are in place. The paper further argues that the violence experienced by refugees (physical, emotional or any other) while in host countries reminds them of the home where they are not welcome. This is desk research that utilised Fanon and African refugee theory to underpin the study.

Keywords: Durable solutions, Great Lakes, violence, geopolitics, refugees 


\section{Introduction}

The examination of the contemporary state of political violence and refugee crisis in the Great Lakes region will help to understand how the colonial notion of the indirect rule remains a challenge in the contemporary states on the African continent. The colonial notion of indirect rule is well explained by Lugard (1926), who argues that the contemporary political landscape in many African states seem to suggest that leadership is meant for certain categories which are more superior and have rights to rule others rather than consensus and it is a present challenge worthy of investigation. However, the description of a superior race for example, the Fulani in Nigeria provides a powerful position about the false assumption of categorizing people. In addition, some categories in the Great Lakes believe they have some sort of God-given superior leadership abilities which makes them a special group. This false assumption is premised on British or Belgian colonial structures inherited by the post-colonial state.

The British policy of indirect rule, for example, provides the minority elites with the power to represent the desires of the masses with no regard to their civil rights (Lugard 2013). One would argue that the elite's attempts to use violent means for their stay in power gives raise to the questions why the United States of America, Britain and France who are considered as external actors continue to play double standards in a violent situation that has displaced millions of people whose constitutional rights are ignored. North, Wallis, Webb, and Weigast (2013) argue that minority elites use violence to sustain themselves in power and as such create a patronage relationship among themselves to manipulate political space through mutual interests, threats, electoral fraud and lucrative work placements. Meanwhile, those who oppose the system are violently harassed, imprisoned or forced into exile and become refugees elsewhere.

Political violence within states is high especially in the context of the Great Lakes region of Africa, is endemic and centres on conflicts. Unfortunately, this part of the world continues to be problematic, without clear solutions leading to refugees scattered within the region and many other parts of the world. The Great Lakes region encompasses the following countries $\underline{\text { Burundi, }}$, the Democratic Republic of Congo, Kenya, Rwanda, Tanzania and Uganda. In the Great Lakes region, most of the countries such as Burundi, Rwanda, Uganda and the Democratic Republic of Congo have suffered most 


\section{Fred Bidandi}

from violence for approximately four decades and the root cause can be traced back to the 1960s. This continues to manifest itself as those who challenge the dictatorship are exiled to foreign countries with their identities that reconnect them with their home country. This paper captures the underlying factors which explain violence and its implications on migration in the context of geopolitical space in the Great Lakes region. An evaluation of the use of durable solutions in the geopolitical space by various political actors is instructive in understanding these implications. The paper also explores and analyses how geopolitical space, identity and political violence have impacted migration, with most emphasis placed on problems of leadership, ruling elites and geopolitics.

This study utilized Fanon's (1961) narrative on violence and Rogge's (1979) African refugee theory both of which describes forced migration and African refugee situation as a complex interplay of social-economic factors such as unemployment, poverty, political violence and persecution among others. Rogge argues that the compound social economic situation may lead to refugee movement and does not affect people in the same manner. In addition, people sometimes move because of a mere rumour of instability according to the qualified argument by Rogge 1979. Though the refugee movement is complex, the situation which creates them varies. For example, those who leave because of fear of persecution or political violence are conditioned by unique situations. However, people have different perceptions of exactly what they consider as a threat to them (Rogge 1979).

Moreover, in other circumstances, people do not flee until they have been overtaken by political violence, membership in a political organisation or government being thrown out of power as we have witnessed in the Great Lakes region countries of Rwanda, DRC, Burundi and Uganda in the recent past. Rogge describes forced migrants as persons expelled from an area by an external force, such as a government and the people involved have absolutely no choice in the matter of their removal. In the Great Lakes region, examples of political violence include the overthrow of the Obotte government in Uganda in the early 1970s by the Idi Amin regime, Museveni overthrow of Tito Okelo in 1986, the 1994 overthrow of the Hutu government in Rwanda and the removal of Mobutu in 1996 respectively all of which have contributed to the flight of many people to flee into exile (Otunnu 2016). Although Rogge (1979) does not specifically address the problems associated with repatriation or return, it can be suggested that refugees would be the most likely to 
participate in repatriation if conditions that made them leave their countries have improved. Meanwhile, Fanon (1961) argues that people who retain a strong attachment to the feeling of the homeland are the ones most likely to be willing/wanting to repatriate beside violence especially when the home regime is oppressive or violent. In the Great Lakes Region context, the majority of the refugees flee because of political violence, indiscriminate arrests, dictatorships, as well as perceived or real state torture. However, Fanon's justification of violence is rationalised by his analysis of the European colonial indirect rule, which he characterizes as inherently violent (Fanon 1961). Though Fanon's justification of violence has been criticised, it provides some significant cues for this paper.

This study utilized secondary data that has been primarily collected by others from sources such as books, the internet, peer review journals, and newspapers to carry out the research (Hox \& Boeijie 2015). Gleit and Graham (1989) postulate that desk research contributes to knowledge developed, by allowing consideration of important questions without some of the limitations different from those of original investigations. The purpose of using secondary data in this study was to delineate factors associated with political violence in the Great Lakes region and also to generate specific testable assumptions for future research. Using desk research provided a broader understanding of how the geopolitical space, and leadership among others seem to be the main factors causing a refugee crisis in the Great Lakes region.

\section{Violence in the Great Lakes Region}

The Great Lakes region countries under investigation have since independence in the early 1960s experienced violence more than any others on the African continent. This experience is seen as a result of the elites in power who have in contemporary times used it as an opportunity to manipulate the electorate for their stay in power through violence (Otunnu 2016). Most recent studies have indicated that countries in the Great Lakes region have ignored peace mechanisms such as dialogue and have instead, resorted to violence (Kanyangara 2016; Otunnu 2016). This shows the great need for dialogue before decisions for voluntary repatriation or integration is made. North et al. (2013) are of the view that each country in the Great Lakes region is unique and beneficial to elites as well as foreign interest, thus making it difficult to deal with violence. I posit that the political elites in the Great Lakes region 


\section{Fred Bidandi}

have used this opportunity to develop their power base at the expense of maintaining status quo with both local and external alliance. In this context excluding those who oppose them which are often referred to as rebels and terrorists. The language applied by these elites does not in any way provide solutions of peace for the displaced refugees but rather encouraging them to use violent means to negotiate their return either through amnesty or by force as we have witnessed in the past for example, the 1979 ouster of Idi Amin by Ugandan refugees exiled in Tanzania, 1994 Rwandese in Uganda, and DRC in 1996 all of whom returned through violent means. This resides in Rogge's (1979) opinion in which he argues that people are forced to flee based on what they consider violent to them. Whilst, Fanon (1961), in his book, The Wretched of the Earth argues that violence produces violence especially when people want to free themselves from repressive regimes. Fanon's description of violence could mean anything especially the violence between a state and opposing sides. Fanon's philosophy of violence is seen as an inevitable part of the struggle for freedom given the nature of the political system in power it attempts to overthrow. Whilst, he postulates that not only violence is to be utilised in the struggle for political freedom, it is also the means by which refugee or displaced persons free themselves from the oppressed rule. Important to note, Fanon does not provide solutions to end violence through mechanisms such as dialogue, rather he leaves both options open.

Nonetheless, political scores in the Great Lakes region appear to be settled by violence based on the evidence given earlier in the text. This underscores the fact that people in countries such as Uganda know, you cannot change the regime through a ballot! In this case, one could be tempted to argue that violence could be the only language the ruling elites could understand. Fanon's description of violence depicts the current political situation in the Great Lakes region as regimes in this part of the world use violence to suppress the critics. However, that is not to say that Fanon promotes violence but his elucidation would mean the healing of wounds has been inflicted. Hannah Arendt, whose book On Violence devotes a great deal of time to refuting what she describes as an undeniable glorification of violence but recognized that Fanon justifies the merits of violence. The notion of justifying violence is perhaps premised on three issues, firstly, failure by ruling elites to recognize the security threat displaced people might pose, secondly, forgetting that they are not nationalities of host governments and thirdly, there are military elements among them. 
The study by Kirui and Mwaruvie (2012) points out that political and military elements intent on cross-border incursions have sought to control and exploit the refugee camps in the Great Lakes region which has become a serious consequence for host countries. Some host countries in the region problematize refugee situation for their geopolitical interest as indicated by witnesses of Uganda and Rwanda on DRC refugees' claims. However, Kirui and Mwaruvie do not provide any solution about the refugee problem despite their acknowledgement of armed elements.

Kitenge (2016) argues that despite the security threats refugees have on the host country; they also poison relations between the country of origin and the country providing asylum. The poisoned relations in this light advance to violence between the countries involved if not cautiously addressed. For example, relations between Tanzania, Rwanda and Burundi were strained between 1994 and 1995 when Tanzania hosted thousands of refugees fleeing the genocide in Rwanda and violence in Burundi (Kitenge 2016). Uganda's relationship with Tanzania in 1972 and with the DRC in 1988 was strained which developed tension because of trans border attacks by rebels intending to oust Idi Amin and later Yoweri Museveni (Osmańczyk \& Mango 2003; Lansford, 2013). This narrative provides synopses of how refugees in the Great Lakes region have over the years contributed to violent hostilities between countries. However, given these experiences, the ruling elites are not concerned about the displaced population.

Davison (1989) clarifies that the colonial imposition of boundaries drawn at the Berlin conference of 1884 by different colonial masters provided a total disregard for ethnic identities and contributed to numerous violent intertribal wars and displacements experienced today in many parts of the African continent. Lugard's (1926) explanation of 'ruling native races' is not in vain as it continues to provide structures for the control of commercial interests in the former colonies. The structures established in the colonial era are a basis for violence as they are tied to the economic importance of countries in the Great Lakes region (Schmelz 2008). The Great Lakes region continues to change the course of history particularly the swift allegiances in the case of Rwanda from France's union to Britain's commonwealth (ibid). The departure of Belgians from Rwanda in 1959 and 1961 led to the formation of a Hutu dominated government established to replace the colonial government which ruled through a Tutsi royal family (Preben 2006) There was a violent attack against the new government under the leadership of Hutus disfranchised minority 


\section{Fred Bidandi}

groups and Tutsis broke out which led to over 300,000 of them fleeing the country to seek refuge in neighbouring Uganda and far afield. This attack was conducted in 1972, by the Tutsi led government of President Micombero, together with paratroopers from the DRC (then Zaire), and led to a wholesale genocide on any Hutu civilians who could not escape. This act cemented power for the Tutsi-Hima ethnic groups. Similar violence broke out in 1988 ending with the death of about 3.000 Tutsi and around 20.000 Hutu people (Brett 2006). The same kind of ethnic violence, spurred on by the fear of the other ethnic group acting first, happened in 1991 and 1993 as well, although on a much smaller scale with hundreds dead (ibid). Consequently, the opposition against Hutus by Tutsi government in neighbouring Burundi incited violence against Tutsis in Rwanda in 1973, resulting in even more refugees, and further escalating asylum seeker population in Uganda (Breben 2006).

The Democratic Republic of Congo has equally experienced a brutal colonial history. Following an upsurge in nationalist sentiment and growing demands for independence, Belgium accepted Congo's independence in June 1960. In 1965 the United States and Belgium ousted President Kasavubu and replaced him with Mobutu Sese Seko (Brett 2006 ). In 1971, Mobutu changed the name of the country to Zaire and systematically used the country's mineral wealth to co-opt potential rivals as well as to enrich himself and his allies through a patronage system with a government whose principal aim was to loot public goods. Following the Rwandan genocide in 1994, Mobutu provided shelter and protection not only to the two million Rwandan refugees who had fled to eastern Congo but also to the Rwandan Hutu army and militias that directed the genocide. This provoked Rwanda and Uganda to invade Congo in July 1996 in pursuit of Hutu military forces. Rwanda and Uganda re-invaded Congo, supporting rebel proxies against Kabila. While Rwandan forces had previously focused primarily on pursuing the Hutus who committed the genocide, both Rwandan and Ugandan forces increasingly became interested in controlling and exploiting the mineral-rich eastern provinces of the Congo under the pretext of fighting rebels threatening peace in the region (Lischer 2005).

Therefore, it is important that we understand the past in order to comprehend the contemporary situation better and possibly the future. Thus violence that has engulfed Rwanda, Burundi, Uganda and the Democratic Republic of Congo can be traced from colonial error.

The study carried out by Shyaka (2008) indicates that though much 
has been written about the emergence of separate ethnic identities through the colonial governance structures, before and after independence in the case of the DRC 1960, Rwanda 1961, Uganda 1962, Burundi 1962 these countries continue to act within the bounds of segregation.

During the 1970s and early 1990s, Rwandan refugees in neighbouring Uganda formed political and military alliances to return home by means of violence forcing again many Hutus into exile in the Democratic Republic of Congo and other parts of the world (Shyaka 2008).

The returnees heightened ethnic tensions and millions of Hutus are now living in camps in neighbouring countries and cities with no explicit solution for their return. Consequently, we are yet to experience another political violence breaking out since there is no amicable solution from the ruling elites especially in Uganda and Rwanda who appear to be peacemakers in the Great Lakes region but forget to remind themselves about the displaced population whose history they share. Mamdani (2009) argues that modern political sensibility is violence that does not make sense. In reality what makes sense to them when people are living in exile, camps or dialogue? The silent voices from the ruling elite and international community do not seem to provide any tangible solutions to the circumstances that are leading to displacement. Malkki (1996) explains that the contemporary political tragedy in the Great Lakes region should not be left to international policy scholarship, but involve scholars across disciplines perhaps in order to examine the persistent political violence.

The refugee circumstances in exile significantly influence the construction and maintenance of national identity which has become a tool to reconnect them with home through means appropriate to them. Malkki's (1996) explanation provides a general trend of the refugee situation in the Great Lakes region whether living in camps or cities. His view demonstrates how the displaced population attach significance to exile but always envision a collective return to the homeland. However, the question remains how do they return?

Though the United High Commission for Refugees (UNHCR 2004) provides voluntary repatriation on individual merit but in principle does not promote a return to countries of origin due to adverse circumstances. One would argue that the return or repatriation requires a collective agency especially the international community, refugees themselves, regional government as well as the UNHCR who may facilitate such returns. During the process of repatriation consideration of the protection risks and benefits on 


\section{Fred Bidandi}

a case-by-case basis, will be a necessary undertaking.

The main challenge to repatriation whether voluntary or otherwise remains a condition conducive to return with some justification to return. It should be noted that refugees, who assimilate themselves in an urban setting and have crafted identities in response to the practical circumstances of their day to day lives, similarly envision returning home through any means available. An example can be seen in the situation in Rwanda and Burundi which appears to be a replica of what is taking place in Uganda and the DRC. Uganda has experienced extended periods of internal violence, similar to that found in Rwanda and Burundi. Brett, Specht and Grey (2005) sum up the postindependent political situation in Uganda in which they argue that the country has seen more 'bullets rather than ballots'. The violent political conditions in Uganda led to the removal of two governments by coups, that is, Obote I-1971 by foreign invasion and Obote II - 1985 by an armed rebellion by NRA and Museveni in 1981-85 that culminated in the overthrow of Tito Okello (1979 Tanzania-Uganda National Liberation Front invasion). All of these were influenced by either refugees internally displaced or exiled.

Otunnu (2016) notes that violence in the Great Lakes region is a result of one ethnic group trying to impose its policies over others, while other political groups fight back to access state power and resources. Rogge (1979) describes such a situation as complex since it appears to be an interplay of social-economic factors such as unemployment, poverty, political violence and power. Arendt (1970:8) asserts that 'violence is nothing more than the most flagrant manifestation of power'. Mills (2000) affirms that all politics is a struggle for power and the ultimate power is violence. This pronouncement echoes Max Weber's definition of the state as 'the rule of men over men based on the means of legitimacy that is allegedly legitimate violence' (Silos 2003). This describes the entrenched paradigm of power, which has a long history of claims that power is the rule of an individual, group, or state over others. If this is the way we think of power, then it makes sense to claim that the ultimate kind of power is violence. Arendt's 1970 conception of power goes to her political thinking that where power reigns, there is persuasion, not violence and when violence reigns, it destroys power. If this is the case, then humanity should re-examine modalities of addressing issues of power and find tangible solutions to end the violence and ultimately allowing displaced people to return through mutual understanding of each other's social, political and economic needs. 
In light of the above, countries such as Burundi have endured the brunt of violence between the years 1972 to 2005 and the cause of this is less similar to that of Rwanda. In the course of Rwanda and Uganda's invention of DRC, many Congolese particularly from the east were driven to exile as refugees. The situation of civilians on the ground, especially women remained dire as the violence of the military tactic against refuges opposing the ruling elite's escalated (Lischer 2005). The end result of military tactics led to the exiled groups fighting back to access state authority and hence the continued escalation of violence. Ugandan, Rwandan, Burundian and DRC political elites have consequently worked out political formulae, not as a means through which violence can be resolved for the ultimate good of the political system but as a strategy for containment (Osmańczyk \& Mango 2003). Furthermore, Osmańczyk and Mango 2003 provide a reflection of how Uganda avoided addressing the refugee problem directly and that strained the relationship with her neighbours as earlier indicated but instead signed the East African Treaty in 2001 for economic integration as an alternative for peace. The signing of the treaties cannot be translated into a solution for negotiating issues of refugees but rather escalated violence through military means. The cardinal effect of failure to obtain a durable solution to these refugees is 'warehousing' of refuges (Azad \& Jasmin 2013). This term is coined to indicate the confinement of refugees in refugee camps, segregated settlements, or deprivation of their rights for a continuous period of ten years or more (World Refugee Survey 2004). UNHCR Statistics show that as at 2003, 6.2 million refugees in 38 different states have been in this refugee crisis. (UNHCR 2004). Given the present statistics, it is a protracted refugee situation, which relates to a person being in exile for a period of 5 years or more (Crisp 2003).

\section{Reflections on Geopolitics and Violence}

There have been some cases in the Great Lakes where persons have been displaced because of the moral differences between them and governments. This has created multifaceted violence and difficulties in making peace in the Great Lakes Region which has been elusive due to geopolitical space, ethnicity and the economic interface between states on one hand and external actors on the other. Kanyangara (2016) postulates that the shared central problems of violence emanate from post-colonial challenges to state-building and the geographical boundaries that extend beyond a nation-state due to ethnic 


\section{Fred Bidandi}

identities that cut across regional states. As seen for example, Uganda's military intervention in Rwanda in 1990 and the DRC in 1996 is premised on ethnic identity in which, Rwanda often justifies its presence in the DRC in part as an effort to protect the Banyamulenge people (Snow 2005). Meanwhile, Uganda claims to be fighting Allied Democratic Forces and the Lord's Resistance Movement rebels wanting to topple Museveni's regime.

Violence in the Great Lakes region is partly related to the complex ethnic politics that has involved multiple regional and international actors. Snow (2005) reveals for example that Rwanda and Uganda continue to benefit from high-level military arrangements with external actors such as the United

States, Canadian mining firm Barrick Gold, Heritage Oil and Gas exploiting mining opportunities in the DRC due to their shared ethnic identities. Additionally, this has helped conglomerates such as Heritage Oil and Gas to secure contracts for the vast oil reserves of the Semliki basin, beneath Lake Albert, on both the Congolese and Ugandan sides of the border. In this light, the nature of violence in this region relating to common features such as governance issues, identity division, exploitation and access to natural resources, are the most prominent (Snow 2005; Kanyangara 2016). The inability of the ruling elites to manage multi-ethnic societies by ensuring political inclusion creates a ripe context for violence since the political elites play on ethnic divisions and prevailing stereotypes. Mandala (1990) argues that the problems in addressing basic needs for various ethnic groups equitably can be seen within the context of state policies that have been weakened by violence, and whose ability to guarantee the security of the life and property of its citizens is diminished. Similarly, Snow (2005) notes that Ugandan and Rwandan military frequently used violence to exploit resources in the DRC. The exploitation of natural resources escalates violence at a regional level. As a result, small arms and financial resources flow across borders, and people are forced to flee their homes and criss-cross the region to escape violence.

Unlike other countries and regions in Africa, conflicts in Burundi, Rwanda, the DRC and Uganda have been motivated by ideology on one hand but on the other by ethnicity or political elites' ability to provoke ethnic violence from their own ends. To understand the regional dimension of ethnicity in the Great Lakes region, one first has to understand that the ethnic distribution of Hutus and Tutsis is not confined within political boundaries. More than two million Hutus and Tutsis are located across the boundaries of Rwanda and Burundi in neighbouring Uganda and the DRC. Some trace their 
ancestry to both the DRC's North Kivu province and western Uganda. Thus, once a conflict with an ethnic factor erupts in Rwanda, Burundi or eastern DRC, it is very easy for politicians and other elites who have direct interests to manipulate and exploit these ethnic ties to create alliances, regardless of the boundaries of these countries (Rietzke \& Robertson 2012).

\section{Dynamics of Elitism}

In the context of this study, elitism refers to a dominant group which controls power through coercion and manipulation (Mills 2000).

It has been observed that since Belgium and Britain took over the Great Lakes region in the 1880 s, the countries in this region have been dominated by the elite. Since independence in the early sixties, no leader has handed over power peacefully. The minority elites remain in control of these countries' resources by means of the gun. Practically the Gunmen have been in charge of the region's countries and as such giving the dominance of the elites and denying their citizens' the right and ownership. The elites' dominance is usually accompanied by state violence which gradually has become a legitimate method of silencing critics of the ruling minority. Concerns have been voiced over restrictions on the activities of rival political forces to the ruling political elites and the concentration of power in the hands of a small group (Mumbi 2013). I argue that the states under investigation are composed of the patron-client type which is a system based on a hierarchical elite relationship in whom state power is centred.

In this respect, North, Wallis, Webb and Weingast, 2013, show that the ruling elites sit at the top but also entrenched in patronage networks that extend down to the rest of society. North, et al. (2013), posit that it is typical among the elites in the Great Lakes region to use threats and violence when their power is threatened and this has become a common trend, for example, in state violence on those who oppose them. Leaders in these countries (Museveni, Kagame, Nkurunziza and Kabila) do not understand the word freedom and democracy, to them, anybody with an opposing view is an enemy hence, domination and force are the only languages they perhaps understand and have mastered (Storey 2012). Meanwhile, Snow (2005) quoted Rwanda's Kagame saying to the United Nations Observer Mission in DRC (MONUC) that 'you have to make war to have peace'. Uganda and Rwanda displaced persons continue to cause violence in eastern DRC because they are adopting 


\section{Fred Bidandi}

the decision to use violence to solve the violence approach leading to a further escalation of violence. The unwillingness by the elites to negotiate peace with the displaced people creates yet another recipe for violence in the Great Lakes. Indeed, the ruling elites claim a commitment to ending sectarianism which they view as a colonial project causing ethnic violence and the refugee crisis. North et al. (2013) suggest that addressing problems of violence and forced displacement requires citizenry shared belief that emphasizes various forms of inclusion and equality. North et al. (2013), elucidate that refraining from violence requires the state to provide stability through open access to political (power sharing), social, economic and other activities, subject to general rules applied objectively.

\section{Dynamics of Leadership and Management of Violence}

The postcolonial Great Lakes region (Rwanda, Burundi, the DRC and Uganda) portrays an image of dictatorships, uncertainty and violence (Shyaka 2008). According to Chazan (1999), the colonial legacy is partly the source of violence and is still essentially problematic simply because the Great Lakes region has been characterized by bad leadership. The roots of this can be attributed to colonial administration, prejudice, exclusion, injustice, unfair political ground (vote-rigging, intimidation, threats and arbitrary arrests), corruption and unequal distribution of national resources as well as power, all of which appears to be the primary indicators of the category of leadership found in these countries. Bad leadership has led to different types of violence not only in the Great Lakes region but on the African continent as a whole. Chazan, (1999) classifies the types of violence as, elite conflicts, factional conflicts, communal conflicts and mass conflicts. All of these violences have been in existence and continue to be experienced in Rwanda, Burundi, Uganda and the DRC at different times. Violent conflicts in the Great Lakes region are both internal and trans-national based on the following types of regime forms dominated; hegemonic, populist, personal coercive and the regime breakdown (Chazan 1999; Shyaka 2008). This suggests that under such circumstances, it is difficult to manage violence, especially when exacerbated by the state. In this light, it has been observed, that all the four countries under investigation have experienced total or partial regime breakdown for example, the DRC in the 1990s, Uganda between the 1970s, 1981 and 1986; Burundi between 1993 and 1996 and Rwanda in 1994 After many years of political violence and 
leaders' failure to reflect on their own history, we have been provided with some valuable insights into the legacy of bad leadership (Shyaka 2008). Jeong (2000) argues that violence in the Great Lakes region is embedded in an inequitable social and economic system, reflecting prolonged exploitation supported by coercion which in this case has become a norm in the Great Lakes countries. This is in line with Rogge's (1979) views in which he argues that the African refugee situation is produced by the interplay of social-economic factors such as unemployment, poverty, political violence and resource exploitation among others. Moreover, political space in the four countries does not meet the concerns of diverse groups of people and as such leading to political erosion which in other words has become the cause of violence (Shyaka 2008).

The impasse of violence and questions around refugees in the Great Lakes region is incumbent upon leadership. Leaders can either choose to make peace or violence depending on the circumstances under which they view their displaced population. The ongoing conflict in eastern Congo, for example, the tension in Burundi, the strained relationship between Uganda and Rwanda are concerns related to leadership as they have made it difficult to pave the way for peace-building and refugee return (McCormick 2015; Kanyakara 2016). The lack of coordination and inability from regional leaders to evaluate the impact of refugee problems requires a bottom-up perspective given the categories of violence. The classic categorization of violence as interstate in the Great Lakes region seems irrelevant since violence geographically shifts from one situation to another (peace and violence). This provides a complex ground for a tangible solution as regional leaders fail to look at the refugee problem from a broader picture, that is a picture, that focuses on the historical factors, root causes, interventions took and possibly failures (Adedejii 1999; Ewald \& Nilsson 2004). Violence in the Great Lakes involves multiple and interlocking regional and international actors who in other words hardly provide durable solutions.

\section{Durable Solutions}

Just like refugees in other areas in Africa, refugees in the Great Lakes regions encounter multiple socio-economic challenges, as they strive to come to terms with leaving home, and surviving in the host or third-party state (Yeboah 2016). While the tension for the refugees is heightened due to leaving home 


\section{Fred Bidandi}

and attempting to settle in the host state; there is a commensurate level of tension, that engulfs the host state with regard to hosting the refugees and offering them basic services, especially where the resources are limited (Yeboah 2016). The limited resources between them and members of the host communities (Milner 2014) exacerbate their challenges for settlement.

The decision to be a refugee and seek recognition is considered a temporary system, with the ultimate objective of obtaining a lasting solution to the refugee's situation (United Nations High Commission for Refugees 2016). According to Boano, Rottlaender, Sanchez-Bayo \& Viliani 2003) the safety and security for refugees in the process of implementing permanent solutions to their problems is key. This model underscores the need for security in the host state or the third party state in a quest for durable solutions (Atfield et al. 2004). The UNHCR provides three types of durable solutions, which are voluntary repatriation of refugees to their countries of origin, local integration of refugees into the host country, and resettlement of refugees in third-party states. These three measures offer a permanent solution to the refugee plight.

A refugee's decision to use voluntary repatriation, to make a free and well-informed decision, to return in safe conditions of legal, physical and material safety, return in dignity, unconditionally, respectfully treated, not separated from family is a daunting task (Crisp 2002). The Global Consultants on International Protection (2004), state that voluntary repatriation is the most sought-after durable by refugees. Although this is a solution, however, it has its own complexities and challenges that are presented in the slow progress of the solution. Measures to embrace the need for the physical safety, and restoration of national protection of prospective nationals, are not yet in place (International Consultants 2004). According to Mooney et al. (2007), the major considerations that a refugee looks at before applying or using voluntary repatriation, include the physical safety or security, availability of social services like skills training, financial assistance, health care, employment, and quality education. Mooney et al. (2007) suggest other factors like shelter, family social support, and psychosocial support services. According to UNHCR (2004), national protection goes beyond physical protection to a progressive realization of all social-economic rights (UNHCR 2012). The International consultants (2004) state that the countries of origin usually have a poor record in respect of human rights, low ability to restore economic, social and political life, or ensuring a vibrant judicial system, and bringing long-term stability. This problem is exacerbated by refugees who have a violent political 
history, as discussed above.

Integration of refugees is a gradual process through which refugees become active participants in the economic, social, cultural, civil, cultural and spiritual affairs of the host state (Cnossen 1964). In Kenya, the Government used integration between 1963 and 1991 (Verdirama 1999). The policy enabled refugees to settle in urban centres other than camps which in some way creates a non-integration policy. The non-integrationist policy of Kenya for example has led to various court cases in a bid to stop the continued abuse of refugee rights (Hannah, 2012). Questions of abuse of the non- refoulement principle still arise, which is an indication that voluntary repatriation is forced on refugees instead of dialogue (Maina 2016; Hannah 2012).

However, local integration in Kenya is exacerbated by ethnic exclusion and marginalization, which is evident in its job market. The author asserts that many communities are marginalized to the extent that available opportunities are offered in terms of tribal orientation. This correlation between governance, politics and ethnicity affects social cohesion, and does give integration a chance to take root. Yeboah (2013) underscores the refugees' expectations in instances of integration which are the provision of security in the host country, non-discrimination against refugees, access to skills training, quality health care, equal employment opportunities, quality education, and the right to own landed properties. These expectations require a good political will and cooperation of a host government to ensure that it is successful. The success of integration is usually hampered by a lack of political will.

Resettlement is used as a tool to absorb the refugees into the local community by either the host state or the third party state (Rutinwa 1996). Therefore similarly, the study suggests that the resettlement in the Great Lakes region has been modelled around three concepts. Firstly, the absorption of the refugees into the host state in return for development assistance from the international community has been addressed with regard to the Rwandan and Burundian refugees in Tanzania. The second model has been the need to create safe zones within the countries of origin for the refugees to return to. This concept was integrated into the Plan of Action for Voluntary Repatriation of Refugees in the Great Lakes region which was adopted by the Intergovernmental Regional Conference in Bujumbura, from 12- 17 February 1995. This model was marked as prospective efforts from the regional leaders. However, it was vibrant on paper but the implementation was lacking. The third aspect would be to address if the root cause and the inability of Rwanda 


\section{Fred Bidandi}

and Burundi are willing to govern themselves (Rutinwa 1996). The chronic issue of violence across the region, and inculcating the process of peace building between the refugees and the local governments in the country of origin can be handled properly if the third option would be addressed.

Some jurisdictions, like Tanzania, have attempted to use a hybrid system, where they pursue integration with resettlement (Milner 2014). These instances of perceived success when dealing with refugees have always stalled due to various reasons, which inform the political discourse in host states. The United Nations High Commission for Refugees has always underscored the need to use durable solutions within a given domestic framework to deal with refugees who have stayed in host nations for protracted periods of time (UNHCR ExCom 2004). Milner (2014) evaluates Tanzania's attempt to use naturalization as a domestic durable solution to the 220,000 Burundian refugees who have been hosted since 1992. Milner (2014) argues that although Tanzania tried to embrace the global policy on refugees through naturalization, the process stalled due to political reasons. The dynamics in Tanzania's domestic politics posited a challenge to resettlement. The global refugee policy informed the formulation and early implementation of Tanzania's naturalization policy, which in itself fails to validate the ability to affect the full implementation of the policy in light of increased domestic opposition to local integration.

\section{UNHCR and Global Policing}

Central to forging solutions or interventions to anticipated return is the fusion of the global policy on refugees with domestic jurisdictions. Loescher (2001) alludes to the fact that the UNHCR has used various examples of collective global efforts to find solutions for prolonged refugee situations. Some of the success stories include the Indochinese refugees of the late 1980s (Loescher 2000). The authors state that the global policies through success stories illustrate the UNHCR's awareness of the political context of their work to commit to refugee protection in instances were a requirement for protection which goes beyond self- interest. This is an indication that global conversations have the ability to engage in meaningful courses of action with the objective of offering lasting solutions to refugee situations (Sorro 1990; Milner 2014). In addition, the UNHCR has to incorporate monitoring activities of the Global Policy, as a way of extending assistance programs to refugee returnees to 
ensure local community benefits from returnees' assistance. Facilitation with the reconciliation process is absent and sharing of information with counterparts in the country of asylum (come and see and tell) is limited but cannot in any way assist the process of repatriation.

\section{Conclusion}

The paper has argued that the contemporary state of political violence and refugee crisis in the Great Lakes region is hinged on colonial indirect rule and leadership challenges.

The British policy of indirect rule, for example, provides the minority elites with the power to represent the desires of the masses with no regard to their civil rights as indicated in the text. The elites have attempted to use violent means for their stay in power and they continue to do so which in many ways has led to displacement of thousands if not millions into exile.

Among the Great Lakes region Burundi, Rwanda, Uganda and the Democratic Republic of Congo have suffered most from violence for approximately four decades and the root cause can be traced back to the 1960s. This paper captureed the underlying factors which explain violence and its implications on migration in the context of geopolitical space in the Great Lakes region. An evaluation of the use of durable solutions in the geopolitical space by various political actors is seen as instructive in understanding these implications. Important to note, the issues discussed in the paper seem to proffer tentative insights and warrant further empirical research.

\section{References}

Adedejii, A. (ed.) 1999. Comprehending and Mastering African Conflicts: The Search for Sustainable Peace and Good Governance. London: Zed Books.

Arendt, H. 1970. On Violence. New York: Rehák David.

Azad, A. \& F.Jasmin 2013. Durable Solutions to the Protracted Refugee Situation: The Case of Rohingyas in Bangladesh. Journal of Indian Research 1,4: 25 - 35.

Boano, C.A., A. Rottlaender, A. Sanchez-Bayo \& F. Viliani 2003. Bridging the Gap: Involuntary Population Movement and Reconstruction Strate- 
gy. Available at:

https://reliefweb.int/sites/reliefweb.int/files/resources/C5035F96369DA

C99C1256DAC00298770-echo-booklet.pdf

(Accessed on 20 September 2005.)

https://doi.org/10.1007/s00467-005-2073-8

Brett, R., I. Specht \& J. Grey 2005. Young Soldiers: Why they Choose to Fight. International Journal 60,44: 1181.

https://doi.org/10.2307/40204117

Chazan, R. 1999. Christian and Jewish Perceptions of 1096: A Case Study of

Trier. Jewish History 13,2: 9 - 22.

https://doi.org/10.1007/BF02336577

Clark, J.F.2001. Explaining Ugandan Intervention in Congo: Evidence and

Interpretations. The Journal of Modern African Studies 39: 261 - 287.

https://doi.org/10.1017/S0022278X01003615

Cnossen, T. 1964. Integration of Refugees. International Migration 2,2: 135 -

153. https://doi.org/10.1111/j.1468-2435.1964.tb00420.x

Crisp, J. 2003. No Solution in Sight: The Problem of Protracted Refugee

Situations in Africa. (New Issues in Refugee Research, UNHCR Working

Paper No. 75.) Geneva: UNHCR.

Ewald, J. \& A. Nilsson (eds.) 2004. A Strategic Conflict Analysis for the Great Lakes Region. Gothenburg: Centre for Africa Studies, Sida. Available at: https://www.sida.se/contentassets/608c2b513ef44b7cbbfd7685b10702c2

la-strategic-conflict-analysis-for-the-great-lakes-region_437.pdf

Fanon, F. 1961. The Wretched of the Earth. Philcox, R (trans.). Forward by Bhabha, H.K. Preface by Sartre, J-P Sartre. New York: Grove Press.

Gleit, C. \& B. Graham 1989. Secondary Data Analysis: A Valuable Resource. Nursing Research 38,6: 380 - 381.

https://doi.org/10.1097/00006199-198911000-00018

Hannah, E. 2012. Refugee Resettlement: The View from Kenya - Findings from Field Research in Nairobi and Kakuma Refugee Camp. Badia, Fiesolana:

Robert Schuman Centre for Advanced Studies 4. Available at: https://www.ecre.org/wp-content/uploads/2013/05/www.know-

reset.eu_files_texts_00695_20130530121940_carim-knowresetrr-2012$\underline{01 . p d f}$

Hox, J.J. \& H.R. Boeije 2015. Data Collection. Primary vs Secondary. Encyclopedia of Social Measurement. 1: 593. Utrecht: Utrecht University. https://doi.org/10.1016/B0-12-369398-5/00041-4 
International Consultant 2004. Protection Policy and Legal Advice Section. Geneva: UNHCR.

Kanyangara, P. (ed.) 2016. Conflict in the Great Lakes Region, Root Causes, Dynamics and Effects. Durban: African Centre for the Constructive Resolution of Disputes.

Khadiagala, G. (ed.) 2006. Security Dynamics in Africa's Great Lake Region. London: Lynne Rienner Publishers.

Kirui, P \& J. Mwaruvie 2012. The Dilemma of Hosting Refugees: A Focus on the Insecurity in Northern-Eastern Kenya. International Journal of Business and Social Science 3: 8.

Kitenge, F. T. (ed.) 2016. Refugees in the Great Lakes Region: Challenges to Peace Building. Durban: African Centre for Constructive Resolution of Disputes.

Lischer, S.K. (ed.) 2005. Dangerous Sanctuaries: Refugee Camps, Civil War and the Dilemmas of Humanitarian Aid. Ithaca, New York: Cornell University Press.

Loescher, G. 2001. The UNHCR and World Politics: A Perilous Path. Refugee Survey Quarterly 20,3.

https://doi.org/10.1093/0199246912.001.0001

Lugard, J.D.F. (ed.) 1926. The Dual Mandate in the British Imperial Africa. California: Blackwood \& Sons.

Lugard, L.F.J. (ed.) 2013. The Dual Mandate in British Tropical Africa. New York \& London: Routledge.

https://doi.org/10.4324/9780203042205

Maina A. 2016. Development of Refugee Law in Kenya: World Policy Blog. Available at: http://www.worldpolicy.org/blog/2016/03/29/developmentrefugee-law-kenya (Accessed on 11 November 2016).

Malkki, L.H. 1996. Speechless Emissaries: Refugees, Humanitarians, and Dehistoricization. American Anthropological Association 11,3: 377 - 404. https://doi.org/10.1525/can.1996.11.3.02a00050

Malkki, L.H. 1995. Purity in Exile: Violence and National Cosmology among the Hutu Refugees in Tanzania. Chicago: University of Chicago Press.

Mamdani, M. 2009. Making Sense of Political Violence in Postcolonial Africa.

Socialist Register 39. Available at:

https://socialistregister.com/index.php/srv/article/view/5796/2692 https://doi.org/10.7208/chicago/9780226190969.001.0001

Mandala, E. 1990. Work and Control in the Peasant Economy: A History of 
the Lower Tchiri Valley in Malawi, 1859-1960. Madison: University of Wisconsin Press.

McCormick, T. 2015. What Really Happened on Burundi's Bloody Friday. Foreignpolicy.com. Available at:

https://foreignpolicy.com/2015/12/14/what-really-happened-onburundis-bloody-friday/

(Accessed on 12 September 2016.)

Mills, C.W. 2000. The Power of the Elite. Oxford: Oxford University Press.

Milner, J. 2014. Can Global Refugee Policy Leverage Durable Solutions?

Lessons from Tanzania's Naturalization of Burundian Refugees. Journal of Refugee Studies 27,4: 553 - 573.

https://doi.org/10.1093/jrs/feu023

Mooney, E., S. Martin, R. Cohen \& C. Beau (eds.) 2007. When Displacement Ends: A Framework for Durable Solutions. Washington, DC: The Brookings Institution, University of Bern.

Mumbi, Z.N. 2013. The Evolution of Elite Manipulation of Ethnicity and Electoral Violence in Kenya (1895-2007): An Emerging Security Challenge for Eastern and Central Africa. Paper presented at the PSS-ISA Joint International Conference, Budapest, June 27-29, 2013.

Niyitunga, E.B. 2015. Impact of 'Global War on Terror' on the Rights of Refugees and Asylum Seekers in the Horn of Africa. Africa Insight 45,3: $46-62$.

North, D.C., J.J. Wallis \& B.R. Weingast (eds.) 2009. Violence and Social Orders: A Conceptual Framework for Interpreting Recorded Human History. New York: Cambridge University Press.

https://doi.org/10.1017/CBO9780511575839

North, D.C., J.J. Wallis, S.B. Webb \& B.R .Weingast (eds.). 2013. In the

Shadow of Violence: Politics, Economics, and the Problems of Development. New York: Cambridge University Press.

Osmańczyk, E. J. \& A. Mango 2003. Encyclopaedia of the United Nations and International Agreements. New York: Routledge.

Otunnu, O. 2016. Crisis of Legitimacy and Political Violence Under the Museveni Regime, 1985-2016. Cham : A Suhrke-Palgrave Macmillan. https://doi.org/10.1007/978-3-319-56047-2

Preben, K. 2006. Violence, Political Culture and Development in Africa. Athens: James Curry Publishers.

Rietzke, D. \& S. Roberson 2012. The Robustness of Enemy of my Friend is 
my Friend Alliances: Proceedings from National Academy of Sciences 112,50: 15277.

Rogge, J. 1979. Some Comments on Definitions and Typologies of Africa's Refugees. Zambian Geography 33,34: 49 - 60.

Rutinwa, B. 1996. The Tanzanian Government's Response to the Rwandan Emergency. Journal Refugee Studies 9:291.

https://doi.org/10.1093/jrs/9.3.291

Sandler, T. 1995. On the Relationship between Democracy and Terrorism.

Terrorism and Political Violence 7,4: 1 - 9.

https://doi.org/10.1080/09546559508427315

Schmelz, A. (ed.) 2008. Post-Colonial Migration and Remembrance Policy in European Immigration Societies: Perspectives of a Cosmopolitan European Citizenship Education. Berlin: Netzwerk Migration in Europe. Shyaka A. 2008. Understanding the Conflicts in the Great Lakes Region: An Overview. Journal of African Conflicts and Peace Studies 1,1: 3. https://doi.org/10.5038/2325-484X.1.1.1

Shyaka, A. 2008 . Understanding the Conflicts in the Great Lakes Region: An Overview. Journal of African Conflicts and Peace Studies 1,1: 5 - 12. https://doi.org/10.5038/2325-484X.1.1.1

Silos, L.R. 2003. The Power of the Leader, Mind and Meaning in Leadership. Quezon: Goodwill Trading Co., Inc.

Smith, M. 2004. Warehousing Refugees: A Denial of Rights, a Waste of Humanity. World Refugee Survey 2004, Warehousing Issue, Washington: US Committee on Refugees.

Snow, K.H. 2005. Rwanda's Secret War: U.S.-backed Destabilization of Central Africa. New York: Z Magazine.

Sorro, G. 1990. Rebuilding the Asylum System: Global Alliance for Open an Society. New York: Open Society Foundation.

UNHCR (United Nations High Commission for Refugees) 2004. Conclusion on Legal Safety Issues in the Context of Voluntary Repatriation of Refugees. UNHCR.

UNHCR 2009. Finding Durable Solutions. Geneva: Evaluation and Policy Analysis Unit, UNHCR.

UNHCR 2012. Frequently Asked Questions about Resettlement: Evaluation and Policy Analysis Unit. Geneva: UNHCR.

Verdirame, G. 1999. Field Report. Human Rights and Refugees: The Case of Kenya (1999). Journal of Refugee Studies 12,1: 54 - 67. 
https://doi.org/10.1093/jrs/12.1.54

Yeboah, I.A. 2016. 'Refugees' Expectations of Durable Solutions to their Problems: Deliberations from the Buduburam Camp in Ghana. Geojournal 81: 427 - 441. https://doi.org/10.1007/s10708-015-9632-8

Fred Bidandi

Centre for Humanities Research University of the Western Cape Republic of South Africa bidandif@gmail.com 